\title{
Synthesis and Spectral Characterization of 4,7-Dichloro-6-nitroquinazoline
}

\author{
Thi Ngoc Nguyen ${ }^{1,2}$, Thi Huong Tran ${ }^{2}$, Nguyet Suong Huyen Dao ${ }^{2}$, Van Giang Nguyen ${ }^{2}$, \\ Dinh Luyen Nguyen ${ }^{2}$, Nguyen Trieu Trinh ${ }^{3}$ and Van Hai Nguyen ${ }^{2, *(1)}$ \\ 1 Department of Pharmaceutical Technology, Thainguyen University of Medicine and Pharmacy, \\ Thainguyen 24117, Vietnam; ngock3a@gmail.com \\ 2 Department of Pharmaceutical Industry, Hanoi University of Pharmacy, Hanoi 110403, Vietnam; \\ huongve2910@gmail.com (T.H.T.); huyendns@hup.edu.vn (N.S.H.D.); giangnv@hup.edu.vn (V.G.N.); \\ ngdluyen@hotmail.com (D.L.N.) \\ 3 School of Environmental and Life Sciences, Faculty of Science, University of Newcastle, \\ Newcastle (Callaghan) 2308, Australia; nguyentrieu@gmail.com \\ * Correspondence: hainv@hup.edu.vn or nguyenvanhaicnd@gmail.com; Tel.: +84-918-971-109
}

Received: 5 April 2020; Accepted: 9 May 2020; Published: 11 May 2020

\begin{abstract}
Afatinib is a 4-anilinoquinazoline tyrosine kinase inhibitor (TKI) in the form of a dimaleate salt which is indicated for the treatment of locally advanced or metastatic non-small cell lung cancer (NSCLC). The most scalable route for the synthesis of this drug was reported in two Boehringer Ingelheim patents, in which the title compound, 4,7-dichloro-6-nitroquinazoline (IV), is an important intermediate. Compound IV is also present in a number of synthetic pathways for various 4,7-disubstituted quinazoline derivatives displaying high therapeutic potential. However, no detailed characterization of this popular compound has been reported, possibly due to its high instability. In this paper, IV was prepared in an overall yield of $56.1 \%$ by a 3-step process (condensation, nitration, and chlorination) from 2-amino-4-chlorobenzoic acid (I). The target compound has been for the first time fully characterized by melting point, mass-spectrometry, FT-IR, ${ }^{1} \mathrm{H}-\mathrm{NMR}$ and ${ }^{13} \mathrm{C}-\mathrm{NMR}$ spectroscopies.
\end{abstract}

Keywords: afatinib; 2-amino-4-chlorobenzoic acid; 4,7-dichloro-6-nitroquinazoline; quinazoline

\section{Introduction}

Quinazoline and quinazolinones scaffolds are present in a diverse range of biologically active compounds with huge therapeutic potential, including anticancer, antimicrobial, antiviral, antituberculosis, antifungal, antimalarial, anti-inflammatory, analgesic, and antidiabetic properties [1-4]. Many quinazoline derivatives, in particular the 4-anilinoquinazolines such as gefitinib, erlotinib, lapatinib, vandetanib, icotinib, afatinib and dacomitinib are approved as tyrosine kinase inhibitors (TKI) for the treatment of different cancers in targeted therapies [5,6]. Among those, afatinib dimaleate is a powerful second-generation TKI, irreversibly binding to both EGFR (epidermal growth factor receptor) and HER2 (human epidermal growth factor receptor 2). It is an approved anticancer drug marketed under the brand names Giotrif ${ }^{\circledR}$ (EU, Japan, Taiwan and Canada) and Gilotrif ${ }^{\circledR}$ (USA). It is indicated for patients with specific types EGFR mutation-positive non-small cell lung cancer $[7,8]$.

The synthetic route to afatinib dimaleate can be derived from two Boehringer Ingelheim patents, comprising 10 reactions [9-14]. In that synthetic procedure, the compound 4,7-dichloro-6-nitroquinazoline (IV, CAS Registry number 162012-71-7) is a highly reactive intermediate. However, it was used in situ and thus no characterization was available. Similarly, in other synthetic routes of other bioactive quinazoline derivatives reported by SciFinder and Reaxys, compound IV 
was also synthesized and used directly in the next step without characterization [15-36], or only partially characterized by ${ }^{1} \mathrm{H}-\mathrm{NMR}$ [37]. The most detailed characterization of $\mathbf{I V}$ includes a melting point analysis, ${ }^{1} \mathrm{H}-\mathrm{NMR}$ and ${ }^{13} \mathrm{C}-\mathrm{NMR}$ spectroscopies, and an elemental analysis [38]. However, it appears that the reported NMR data for IV in this paper are close to those of the starting material (7-chloro-6-nitroquinazolin-4(3H)-one, III), indicating the possibility of a hydrolysis reaction which converts IV back to the starting material. In addition, the given elemental analysis did not present the percentage of each element, which offers no clarification over the identity of this compound. In this paper, compound IV has been for the first time fully characterized by melting point, mass-spectrometry, FT-IR, ${ }^{1} \mathrm{H}-\mathrm{NMR}$ and ${ }^{13} \mathrm{C}-\mathrm{NMR}$ spectroscopies.

\section{Results and Discussion}

The target compound IV was prepared in three steps from 2-amino-4-chlorobenzoic acid (I) in an overall yield of $56.1 \%$ (Scheme 1 ). The synthetic procedures were based on references $[30,33,39]$ with some changes.
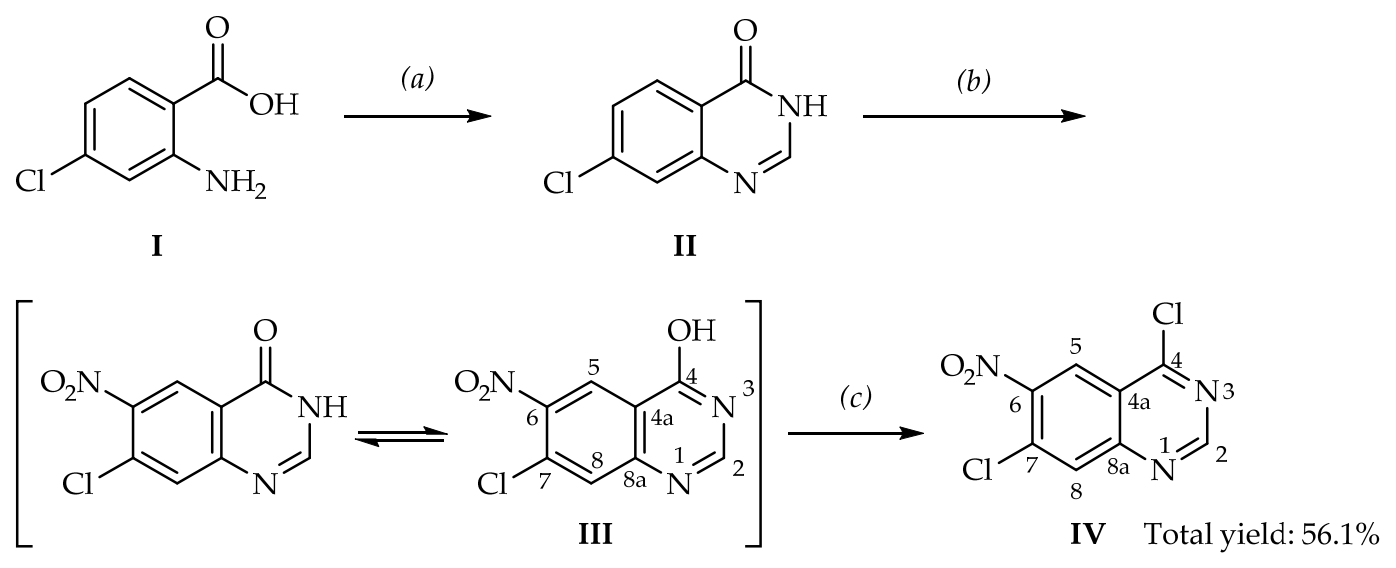

Scheme 1. Synthesis of 4,7-dichloro-6-nitroquinazoline (IV). Reagents and conditions (yield): (a) $\mathrm{HCO}-\mathrm{NH}_{2}$, reflux at $160{ }^{\circ} \mathrm{C}(82.3 \%)$; (b) $\mathrm{HNO}_{3} / \mathrm{H}_{2} \mathrm{SO}_{4}(84.7 \%)$; (c) $\mathrm{SOCl}_{2} / \mathrm{DMF}$ at $100{ }^{\circ} \mathrm{C}(91.3 \%)$.

Compound IV is an imidoyl halide (also known as imidyl or iminochlorides), a group of highly reactive organic compounds widely used as synthetic tools to produce a variety of compounds. It is often not necessary to isolate imidoyl halides because in situ generation and subsequent reactions can afford the desired derivatives in high yields [40-42]. In fact, our experimental observations demonstrate that IV is extremely sensitive to moisture and can be readily hydrolyzed giving back the starting material III. This phenomenon could explain the reason why the NMR-data in the aforementioned article [38] are so close to those of the starting material III. These data are presented in Tables 1 and 2.

Table 1. Reported and our data for ${ }^{1} \mathrm{H}-\mathrm{NMR}$ spectroscopies of III and IV.

\begin{tabular}{|c|c|c|c|c|c|c|c|}
\hline \multirow{2}{*}{ Signals } & \multicolumn{4}{|c|}{$\delta(\mathrm{ppm})$ for Compound III } & \multicolumn{3}{|c|}{$\delta$ (ppm) for Compound IV } \\
\hline & $\begin{array}{l}\text { Ref }[30] \text { (in } \\
\left.\text { DMSO- } d_{6}\right)\end{array}$ & $\begin{array}{l}\text { Ref [43] (in } \\
\left.\text { DMSO- } d_{6}\right)\end{array}$ & $\begin{array}{l}\text { Ref [39] (in } \\
\text { DMSO- } d_{6} \text { ) }\end{array}$ & $\begin{array}{c}\text { Our Data (in } \\
\text { DMSO- } d_{6} \text { ) }\end{array}$ & $\begin{array}{l}\text { Ref [38] (in } \\
\text { DMSO- } d_{6} \text { ) }\end{array}$ & $\begin{array}{l}\text { Ref }[37] \text { (in } \\
\left.\text { DMSO- } d_{6}\right)\end{array}$ & $\begin{array}{l}\text { Our Data (in } \\
\left.\mathrm{CDCl}_{3}\right)\end{array}$ \\
\hline $\begin{array}{l}\mathrm{OH} \text { or } \mathrm{NH} \\
\text { forms }\end{array}$ & $\begin{array}{c}3.30 * \text { (br.s, } 1 \mathrm{H}, \\
\mathrm{NH} \text { form })\end{array}$ & $\begin{array}{c}12.79 \text { (br.s, } 1 \mathrm{H}, \\
\text { OH form) }\end{array}$ & $\begin{array}{c}12.79 \text { (br.s, } 1 \mathrm{H}, \\
\text { OH form) }\end{array}$ & $\begin{array}{c}12.73 \text { (br.s, } 1 \mathrm{H}, \\
\text { OH form) }\end{array}$ & $\mathrm{NA}^{* *}$ & NA & NA \\
\hline H-5 & $8.53(\mathrm{~s}, 1 \mathrm{H})$ & $8.69(\mathrm{~s}, 1 \mathrm{H})$ & $8.67(\mathrm{~s}, 1 \mathrm{H})$ & $8.64(\mathrm{~s}, 1 \mathrm{H})$ & $8.60(\mathrm{~s}, 1 \mathrm{H})$ & $9.56(\mathrm{~s}, 1 \mathrm{H})$ & $9.18(\mathrm{~s}, 1 \mathrm{H})$ \\
\hline $\mathrm{H}-2$ & $8.28(\mathrm{~s}, 1 \mathrm{H})$ & $8.32(\mathrm{~s}, 1 \mathrm{H})$ & $8.31(\mathrm{~s}, 1 \mathrm{H})$ & $8.27(\mathrm{~s}, 1 \mathrm{H})$ & $8.27(\mathrm{~s}, 1 \mathrm{H})$ & $8.71(\mathrm{~s}, 1 \mathrm{H})$ & $8.76(\mathrm{~s}, 1 \mathrm{H})$ \\
\hline $\mathrm{H}-8$ & $7.97(\mathrm{~s}, 1 \mathrm{H})$ & $8.03(\mathrm{~s}, 1 \mathrm{H})$ & $8.01(\mathrm{~s}, 1 \mathrm{H})$ & $7.97(\mathrm{~s}, 1 \mathrm{H})$ & $7.85(\mathrm{~s}, 1 \mathrm{H})$ & $8.28(\mathrm{~s}, 1 \mathrm{H})$ & $8.30(\mathrm{~s}, 1 \mathrm{H})$ \\
\hline
\end{tabular}


Table 2. Reported and our data for ${ }^{13} \mathrm{C}-\mathrm{NMR}$ spectroscopies of III and IV.

\begin{tabular}{|c|c|c|c|c|}
\hline \multirow{2}{*}{ Signals } & \multicolumn{2}{|c|}{$\delta(\mathrm{ppm})$ for Compound III } & \multicolumn{2}{|c|}{$\delta$ (ppm) for Compound IV } \\
\hline & Literature & Our Data (in DMSO- $d_{6}$ ) & Ref [38] (in DMSO- $d_{6}$ ) & Our Data (in $\mathrm{CDCl}_{3}$ ) \\
\hline$C-4$ & NA & 159.3 & 159.0 & 163.6 \\
\hline$C-2$ & NA & 151.5 & 150.3 & 156.9 \\
\hline$C-8 a$ & NA & 149.6 & 149.2 & 151.6 \\
\hline$C-6$ & NA & 144.7 & 144.8 & 147.5 \\
\hline C-7 & NA & 130.4 & 131.1 & 132.8 \\
\hline C-8 & NA & 129.4 & 129.4 & 132.2 \\
\hline C-5 & NA & 124.2 & 124.2 & 123.5 \\
\hline$C-4 a$ & NA & 121.7 & 121.4 & 122.1 \\
\hline
\end{tabular}

The data in Table 1 indicate that III is capable of tautomerism between the lactim $(-\mathrm{C}(\mathrm{OH})=\mathrm{N}-)$ and lactam $(-\mathrm{C}(=\mathrm{O})-\mathrm{NH}-)$ forms, displaying a huge difference in chemical shifts between the $-\mathrm{OH}$ and the $-\mathrm{NH}$ groups (12.79 ppm vs. $3.30 \mathrm{ppm}$ ). In the latter form, the -NH- signal is actually overlapped with the water signal if DMSO- $d_{6}$ is used and may not be seen in a proton spectrum. As the reported proton chemical shifts for compound IV in [38] are similar to those of compound III in [30], we suspect that they are of the same chemical compound (Table 1). Indeed, the ${ }^{1} \mathrm{H}-\mathrm{NMR}$ values for compound IV in [38] do not match up with those of either our data or another paper [37], displaying large chemical shifts' differences of $0.96 \mathrm{ppm}, 0.44 \mathrm{ppm}$, and $0.43 \mathrm{ppm}$, respectively, for the aromatic hydrogens in DMSO- $d_{6}[37,38]$. We would not expect such large discrepancies in chemical shifts for the same compound using the same NMR solvent $\left(\right.$ DMSO- $\left.d_{6}\right)$. When comparing our ${ }^{1} \mathrm{H}-\mathrm{NMR}$ data with those of [37], the differences are $-0.38 \mathrm{ppm}, 0.05 \mathrm{ppm}$, and $0.02 \mathrm{ppm}$, respectively, which indicate a high level of spectral similarities. These slight deviations could potentially originate from the fact that two different NMR solvents (DMSO- $d_{6}$ vs. $\mathrm{CDCl}_{3}$ ) were used [44]. On the other hand, when examining the ${ }^{13} \mathrm{C}$-NMR data, we found strikingly similar values between IV of reference [38] and the starting material III ( $\Delta \delta=0-0.4 \mathrm{ppm}$, Table 2). These reported values are different from our ${ }^{13} \mathrm{C}-\mathrm{NMR}$ data of IV $\left(\Delta \delta=0.4-5.4 \mathrm{ppm}\right.$, Table 2). Altogether, both the ${ }^{1} \mathrm{H}-\mathrm{NMR}$ and ${ }^{13} \mathrm{C}-\mathrm{NMR}$ data combined indicate that the reported NMR data in [38] could potentially be that of the starting material III, and not the desired compound IV. One possible explanation could be the hydrolysis of the highly reactive compound IV back into the starting material III, a phenomenon we have observed in our laboratory.

Another interesting fact is that, when measuring mass spectrometry, we not only detected the peak of compound IV, but also its methoxy form (compound V), which possibly occurs due to alcoholysis by methanol (the solvent in MS). We show this in Scheme 2.<smiles>O=[N+]([O-])c1cc2c(Cl)ncnc2cc1Cl</smiles>

IV<smiles>COc1ncnc2cc(Cl)c([N+](=O)[O-])cc12</smiles>

V
Chemical Formula: $\mathrm{C}_{9} \mathrm{H}_{6} \mathrm{ClN}_{3} \mathrm{O}_{3}$

Calc. $m / z: 240.02(100.0 \%), 242.01(32.0 \%)[\mathrm{M}+\mathrm{H}]^{+}$

Found $m / z: 240.00(100.0 \%), 241.99(30.1 \%)[\mathrm{M}+\mathrm{H}]^{+}$

Scheme 2. The formation of 7-chloro-4-methoxy-6-nitroquinazoline (V) by alcoholysis with methanol in MS.

On the whole, in the synthesis of $\mathbf{I V}$, our control of anhydrous reaction conditions and the appropriate work-up procedures have made it feasible to synthesize and characterize this highly reactive compound for the first time. These data may be useful for further investigations in the synthesis process improvement of afatinib, its analogs and other biologically active quinazoline based compounds. All the mass, FT-IR, ${ }^{1} \mathrm{H}-\mathrm{NMR}$ and ${ }^{13} \mathrm{C}-\mathrm{NMR}$ spectra are presented in the Supplementary Material File. 


\section{Materials and Methods}

\subsection{General Information}

The 2-amino-4-chlorobenzoic acid was purchased from Energy Chemical (Zhejiang, China) and used as received. Formamide (99.5\%) was purchased from Scharlau Chemie (Barcelona, Spain). Thionyl chloride (99.5\%) was purchased from Merck Schuchardt (Hohenbrunn, Germany). Dichloromethane (DCM, 99.5\%), sufuric acid (98\%) and N,N-dimethylformamide (DMF, 99.5\%) was purchased from Xilong Scientific Co., Ltd. (Shantou, China). Fuming nitric acid (d $1.50 \mathrm{~g} / \mathrm{mL}$ ) was prepared by reaction of solid sodium nitrate and liquid sulfuric acid (98\%), following distillation at b.p $82{ }^{\circ} \mathrm{C}$.

The melting point was determined using a SRS EZ-Melt apparatus (Stanford Research Systems, Sunnyvale, CA, USA) and is uncorrected. MS was performed at a EVOQ Qube ${ }^{\mathrm{TM}}$ (Bruker, Billerica, MA, USA) or an LTQ Orbitrap XL TM (Thermo Scientific, Waltham, MA, USA) system. FT-IR spectra were recorded by a Perkin Elmer (Waltham, MA, USA) or Shimadzu (Kyoto, Japan) spectrometer. ${ }^{1} \mathrm{H}$ and ${ }^{13} \mathrm{C}$-NMR spectra were acquired with a $500 \mathrm{MHz}$ Ascent spectrometer (Bruker, Billerica, MA, USA) using acetone- $d_{6}, \mathrm{DMSO}-d_{6}, \mathrm{Cr}_{\mathrm{CDCl}}$ as the solvent. The reaction mixtures were monitored, and the purity of all products was checked by thin-layer chromatography (TLC) on silica gel $60 \mathrm{~F}_{254}$ plates (Merck, Darmstadt, Germany).

\subsection{Synthetic Procedure}

\subsubsection{Preparation of 7-Chloroquinazolin-4(3H)-one (II)}

The synthetic procedure for compound II was based on the method described in [39] with some modifications. A mixture of 2-amino-4-chlorobenzoic acid (I, $34.30 \mathrm{~g}, 0.20 \mathrm{~mol}, 1$ equiv.), formamide (125.0 mL, 2.77 mol, 14 equiv.) was aerated with nitrogen, then stirred and refluxed for $1.5 \mathrm{~h}$ at $160{ }^{\circ} \mathrm{C}$ (the reaction was monitored by TLC with a 9:1 DCM/methanol mixture as eluent). The reaction mixture was cooled to $80^{\circ} \mathrm{C}$, then $500 \mathrm{~mL}$ of water was added. The mixture was cooled to $-5^{\circ} \mathrm{C}$ in $1 \mathrm{~h}$ and filtered. The precipitate was washed with water and dried at $60^{\circ} \mathrm{C}$ to afford 7-chloroquinazolin-4(3H)-one (II) as a light brown solid $(29.71 \mathrm{~g}, 82.3 \%)$, which was used for the next step without further purification. M.p 251.0-253.0 ${ }^{\circ} \mathrm{C}$. $\mathrm{R}_{f} 0.60$ (DCM/methanol, 9:1). MS (ESI $\left.{ }^{+}, \mathrm{MeOH}\right), m / z$ : found 181.2 and 183.2 $\left[\mathrm{M}+\mathrm{H}^{+}, \mathrm{C}_{8} \mathrm{H}_{5} \mathrm{ON}_{2} \mathrm{Cl}\right.$ requires $[\mathrm{M}+\mathrm{H}]^{+} 181.0$ and 183.0. FT-IR $(\mathrm{KBr}), v_{\max }\left(\mathrm{cm}^{-1}\right): 3031(\mathrm{C}-\mathrm{H}) ; 2964$, $2919(\mathrm{~N}-\mathrm{H}) ; 1714(\mathrm{C}=\mathrm{O}) ; 1693(\mathrm{C}=\mathrm{N}) ; 1655,1606(\mathrm{C}=\mathrm{C}) .{ }^{1} \mathrm{H}-\mathrm{NMR}$ (acetone- $\left.d_{6}\right), \delta(\mathrm{ppm}): 11.82$ (br.s, $1 \mathrm{H}, \mathrm{H}-3, \mathrm{NH}) ; 8.17$ (d, J = 8,5 Hz, 1H, H-5); 8.09 (s, 1H, H-2); 7.67 (d, J = $2.0 \mathrm{~Hz}, 1 \mathrm{H}, \mathrm{H}-8) ; 7.51$ (dd, $\left.J_{1}=8.5 \mathrm{~Hz}, J_{2}=2.0 \mathrm{~Hz}, 1 \mathrm{H}, \mathrm{H}-6\right) .{ }^{13} \mathrm{C}-\mathrm{NMR}$ (acetone- $\left.d_{6}\right), \delta(\mathrm{ppm}): 160.6(\mathrm{C}-4) ; 151.2(\mathrm{C}-8 \mathrm{a}) ; 147.3(\mathrm{C}-2)$; 140.2 (C-7); 128.8 (C-5); 127.7 (C-6); 127.6 (C-8); 122.8 (C-4a).

\subsubsection{Preparation of 7-Chloro-6-nitroquinazolin-4(3H)-one (7-Chloro-4-hydroxy-6-nitroquinazoline, III)}

The synthetic procedure for compound III was based on [30] with some modifications. Compound II (10.83 g, $0.060 \mathrm{~mol})$ and sulfuric acid $(120 \mathrm{~mL})$ were added into a $500 \mathrm{~mL}$ two-neck round bottom flask. The mixture was cooled to $0^{\circ} \mathrm{C}$ on ice and stirred until dissolution. Fuming nitric acid (120 mL) was slowly added to the mixture at $0^{\circ} \mathrm{C}$, and the mixture was stirred for $1.5 \mathrm{~h}$ at $30^{\circ} \mathrm{C}$. After completion of reaction as indicated by TLC, $10 \% \mathrm{NaOH}$ solution was slowly added to the reaction mixture until a precipitate was formed ( $\mathrm{pH} \sim 7$ ). The mixture was then filtered to furnish a light yellow solid (III). The compound was purified by redissolving in $\mathrm{HCl}(5 \mathrm{M})$ and then neutralizing this solution with $\mathrm{NaOH}(10 \%)$ to $\mathrm{pH} 6-7$ to furnish the pure precipitate which was then filtered, washed with water and dried at $60{ }^{\circ} \mathrm{C}$ to furnish 7-chloro-6-nitroquinazolin-4(3H)-one (III) as a light yellow solid (11.46 g, 84.7\%). M.p 263.5-265.0 ${ }^{\circ} \mathrm{C} . \mathrm{R}_{f} 0.34$ (DCM/methanol, 20:1). MS (ESI $\left.{ }^{+}, \mathrm{MeOH}\right), m / z$ : found 225.9 $[\mathrm{M}+\mathrm{H}]^{+}, \mathrm{C}_{8} \mathrm{H}_{4} \mathrm{O}_{3} \mathrm{~N}_{3} \mathrm{Cl}$ requires $[\mathrm{M}+\mathrm{H}]^{+}$225.9. FT-IR $(\mathrm{KBr}), v_{\max }\left(\mathrm{cm}^{-1}\right): 3452,3215(\mathrm{O}-\mathrm{H}) ; 3091$, $3012(\mathrm{C}-\mathrm{H}) ; 1696(\mathrm{C}=\mathrm{O}) ; 1666,1612(\mathrm{C}=\mathrm{N}) ; 1523(\mathrm{C}=\mathrm{C}) ; 1336\left(\mathrm{NO}_{2}\right) .{ }^{1} \mathrm{H}-\mathrm{NMR}\left(\mathrm{DMSO}-d_{6}\right), \delta(\mathrm{ppm})$ : 
12.73 (br.s, $1 \mathrm{H}, \mathrm{OH}) ; 8.64$ (s, $1 \mathrm{H}, \mathrm{H}-5) ; 8.27$ (s, $1 \mathrm{H}, \mathrm{H}-2) ; 7.97$ (s, 1H, H-8). ${ }^{13} \mathrm{C}-\mathrm{NMR}$ (DMSO- $d_{6}$ ), $\delta$ (ppm): 159.3 (C-4); 151.5 (C-8a); 149.6 (C-2); 144.7 (C-6); 130.4 (C-7); 129.9 (C-5); 124.2 (C-8); 121.7 (C-4a).

\subsubsection{Preparation of 4,7-Dichloro-6-nitroquinazoline (IV)}

The synthetic procedure for compound IV was based on [33] with some modifications. A mixture of compound III $(6.09 \mathrm{~g}, 0.027 \mathrm{~mol})$, thionyl chloride $(48.0 \mathrm{~mL}, 0.661 \mathrm{~mol})$ and $\mathrm{N}, \mathrm{N}$-dimethyl-formamide $(0.25 \mathrm{~mL})$ was melted and stirred at $100{ }^{\circ} \mathrm{C}$ for $2 \mathrm{~h}$. The reaction mixture was allowed to cool down and excess thionyl chloride was removed by rotary evaporation under reduced pressure. Toluene $(40 \mathrm{~mL})$ was added to the residue and the mixture was evaporated again to completely remove volatile matter. The precipitate was washed with diethyl ether and dried in the desiccator to obtain 4,7-dichloro-6-nitroquinazoline (IV) as a yellow solid (6.02 g, 91.3\%). M.p: $269.0-270.5^{\circ} \mathrm{C}$. $\mathrm{R}_{f}: 0.87$ (DCM/methanol, 20:1). MS (ESI $\left.{ }^{+}, \mathrm{MeOH}\right), \mathrm{m} / z$ : found $244.4[\mathrm{M}+\mathrm{H}]^{+}, 240.00$ and 241.99 [methoxy form]; $\mathrm{C}_{8} \mathrm{H}_{3} \mathrm{O}_{2} \mathrm{~N}_{3} \mathrm{Cl}_{2}$ requires $[\mathrm{M}+\mathrm{H}]^{+} 244.0$ and 246.0. FT-IR $(\mathrm{KBr}), v_{\max }\left(\mathrm{cm}^{-1}\right)$ : $3089(\mathrm{C}-\mathrm{H}) ; 1726$, 1645, $1610(\mathrm{C}=\mathrm{N}) ; 1546(\mathrm{C}=\mathrm{C}) ; 1527,1323\left(\mathrm{NO}_{2}\right) .{ }^{1} \mathrm{H}-\mathrm{NMR}\left(\mathrm{CDCl}_{3}\right), \delta(\mathrm{ppm}): 9.18$ (s, 1H, H-2); 8.76 (s, 1H, H-5); 8.30 (s, 1H, H-8). ${ }^{13} \mathrm{C}-\mathrm{NMR}\left(\mathrm{CDCl}_{3}\right), \delta$ (ppm): 163.6 (C-4); 156.9 (C-2); 151.6 (C-8a); 147.5 (C-6); 132.8 (C-7); 132.2 (C-8); 123.5 (C-5); 122.1 (C-4a).

Supplementary Materials: Spectral data of starting material I, intermediates II, III and title compound IV are available online, Figure S1: FT-IR spectrum of compound 2-amino-4-chlorobenzoic acid (I), Figure S2: ${ }^{1} \mathrm{H}-\mathrm{NMR}$ spectrum of compound 2-amino-4-chlorobenzoic acid (I), Figure S3: ${ }^{13} \mathrm{C}-\mathrm{NMR}$ spectrum of compound 2-amino-4-chlorobenzoic acid (I), Figure S4: MS spectrum of compound 7-chloroquinazolin-4(3H)-one (II), Figure S5: FT-IR spectrum of compound 7-chloroquinazolin-4(3H)-one (II), Figure S6: ${ }^{1} \mathrm{H}-\mathrm{NMR}$ spectrum of compound 7-chloroquinazolin-4(3H)-one (II), Figure S7: ${ }^{13} \mathrm{C}-\mathrm{NMR}$ spectrum of compound 7-chloroquinazolin-4(3H)-one (II), Figure S8: MS spectrum of compound 7-chloro-6-nitroquinazolin-4(3H)-one (III), Figure S9: FT-IR spectrum of compound 7-chloro-6-nitroquinazolin-4(3H)-one (III), Figure S10: ${ }^{1} \mathrm{H}-\mathrm{NMR}$ spectrum of compound 7-chloro-6-nitroquinazolin-4(3H)-one (III), Figure S11: ${ }^{13} \mathrm{C}-\mathrm{NMR}$ spectrum of compound 7-chloro-6-nitroquinazolin-4(3H)-one (III), Figure S12: MS spectrum of compound 4,7-dichloro-6-nitroquinazoline (IV), Figure S13: FT-IR spectrum of compound 4,7-dichloro-6-nitroquinazoline (IV), Figure S14: ${ }^{1} \mathrm{H}-\mathrm{NMR}$ spectrum of compound 4,7-dichloro-6-nitroquinazoline (IV), Figure S15: ${ }^{13} \mathrm{C}-\mathrm{NMR}$ spectrum of compound 4,7-dichloro-6-nitroquinazoline (IV).

Author Contributions: T.N.N. and T.H.T. synthesized the compounds. T.N.N. wrote the manuscript. N.S.H.D., V.G.N. and D.L.N. designed the experiments. V.H.N. analyzed spectroscopic data. V.H.N. and N.T.T. edited the manuscript. All authors read and approved the final version of the manuscript.

Funding: This research received no external funding.

Acknowledgments: The authors would like to thank Hanoi University of Pharmacy and Thainguyen University of Medicine and Pharmacy for financial support and research facilities.

Conflicts of Interest: The authors declare no conflict of interest.

\section{References}

1. Khan, I.; Zaib, S.; Batool, S.; Abbas, N.; Ashraf, Z.; Iqbal, J.; Saeed, A. Quinazolines and quinazolinones as ubiquitous structural fragments in medicinal chemistry: An update on the development of synthetic methods and pharmacological diversification. Bioorg. Med. Chem. 2016, 24, 2361-2381. [CrossRef] [PubMed]

2. Hameed, A.; Al-Rashida, M.; Uroos, M.; Ali, S.A.; Arshia; Ishtiaq, M.; Khan, M. Quinazoline and quinazolinone as important medicinal scaffolds: A comparative patent review (2011-2016). Expert Opin. Ther. Pat. 2018, 28, 281-297. [CrossRef] [PubMed]

3. Das, D.; Hong, J. Recent advancements of 4-aminoquinazoline derivatives as kinase inhibitors and their applications in medicinal chemistry. Eur. J. Med. Chem. 2019, 170, 55-72. [CrossRef] [PubMed]

4. Gatadi, S.; Lakshmi, T.V.; Nanduri, S. 4(3H)-Quinazolinone derivatives: Promising antibacterial drug leads. Eur. J. Med. Chem. 2019, 170, 157-172. [CrossRef] [PubMed]

5. Shagufta; Ahmad, I. An insight into the therapeutic potential of quinazoline derivatives as anticancer agents. MedChemComm 2017, 8, 871-885. [CrossRef] [PubMed] 
6. Buonerba, C.; Iaccarino, S.; Dolce, P.; Pagliuca, M.; Izzo, M.; Scafuri, L.; Costabile, F.; Riccio, V.; Ribera, D.; Mucci, B.; et al. Predictors of outcomes in patients with EGFR-mutated non-small cell lung cancer receiving EGFR tyrosine kinase inhibitors: A systematic review and meta-analysis. Cancers 2019, 11, 1259. [CrossRef] [PubMed]

7. Deeks, E.D.; Keating, G.M. Afatinib in advanced NSCLC: A profile of its use. Drugs Ther. Perspect. 2018, 34, 89-98. [CrossRef] [PubMed]

8. Boehringer Ingelheim International GmbH. Available online: https://www.boehringer-ingelheim.com/ oncology/lung-cancer/giotrif-gilotrif-afatinib-approved-nsclc (accessed on 4 February 2020).

9. Himmelsbach, F.; Langkopf, E.; Blech, S.; Jung, B.; Baum, A.; Solca, F. Quinazoline Derivatives, Medicaments Containing Said Compounds, Their Utilization and Method for the Production Thereof. PCT Patent WO200250043A1, 27 June 2002.

10. Soyka, R.; Rall, W.; Schnaubelt, J.; Sieger, P.; Kulinna, C. Process for Preparing Amino Crotonyl Compounds. U.S. Patent 20050085495A1, 21 April 2005.

11. Schroeder, J.; Dziewas, G.; Fachinger, T.; Jaeger, B.; Reichel, C.; Renner, S. Process for Preparing Aminocrotonylamino-Substituted Quinazoline Derivatives. U.S. Patent US8188274B2, 29 May 2012.

12. Xu, X. Method for Preparing Afatinib and Intermediate Thereof. PCT Patent WO2014180271A1, 13 November 2014.

13. Xu, X. Afatinib and Preparation Method of Intermediate Thereof. PCT Patent WO2014183560A1, 20 November 2014.

14. Ding, H.X.; Leverett, C.A.; Kyne, R.E., Jr.; Liu, K.K.C.; Fink, S.J.; Flick, A.C.; O’Donnell, C.J. Synthetic approaches to the 2013 new drugs. Bioorg. Med. Chem. 2015, 23, 1895-1922. [CrossRef] [PubMed]

15. Barker, A.J. Quinazoline Derivatives and Their Use as Anti-Cancer Agents. European Patent EP0635498A1, 25 January 1995.

16. Barker, A.J. Quinazoline Derivative. PCT Patent WO1996033981A1, 17 May 1996.

17. Brown, D.S.; Morris, J.J.; Thomas, A.P. Aniline Derivatives. PCT Patent WO1996015118A1, 23 May 1996.

18. Barker, A.J. Quinazoline Derivatives. PCT Patent WO9616960A1, 6 June 1996.

19. Thomas, A.P.; Hennequin, L.F.A.; Johnstone, C.; Stokes, E.S.E.; Lohmann, J.-J.M.; Clayton, E. Quinazoline Derivatives and Pharmaceutical Compositions Containing Them. PCT Patent WO1998013354A1, 2 April 1998.

20. Barker, A.J. Quinazoline Derivative. U.S. Patent US5952333A, 14 September 1999.

21. Tobe, M.; Isobe, Y.; Tomizawa, H.; Matsumoto, M.; Obara, F.; Nagasaki, T.; Hayashi, H. Structure-activity relationships of quinazoline derivatives: Dual-acting compounds with inhibitory activities toward both TNF- $\alpha$ production and T cell proliferation. Bioorg. Med. Chem. Lett. 2001, 11, 545-548. [CrossRef]

22. Tobe, M.; Isobe, Y.; Tomizawa, H.; Nagasaki, T.; Takahashi, H.; Fukazawa, T.; Hayashi, H. Discovery of quinazolines as a novel structural class of potent inhibitors of NF-kB activation. Bioorg. Med. Chem. 2003, 11, 383-391. [CrossRef]

23. Matsuno, K.; Seishi, T.; Nakajima, T.; Ichimura, M.; Giese, N.A.; Yu, J.-C.; Oda, S.; Nomoto, Y. Potent and selective inhibitors of platelet-derived growth factor receptor phosphorylation. Part 4: Structure-activity relationships for substituents on the quinazoline moiety of 4-[4-(N-substituted(thio)carbamoyl)-1-piperazinyl]-6,7-dimethoxyquinazoline derivatives. Bioorg. Med. Chem. Lett. 2003, 13, 3001-3004. [CrossRef] [PubMed]

24. Ahn, S.K.; Lee, S.; Choi, N.S.; Lee, J.K.; Moon, S.K.; Choi, H.; Kim, S.J.; Kim, Y.H.; Kang, S.K.; Lee, H.W.; et al. Quinazoline Derivative as Phosphodiesterase Inhibitor and a Process for Preparing the Same. PCT Patent WO2008020711A1, 21 February 2008.

25. Guo, J.; Wang, M.; Jiang, Y.; Zhang, X. Quinazoline Derivatives, Preparation Methods and Uses Thereof. European Patent EP1990337A1, 12 November 2008.

26. Jiang, Y.; Guo, J. Medical Application of 4-Anilinoquinazoline Derivatives. CN Patent CN101347433A, 21 January 2009.

27. Tang, T.; Yu, L.; Feng, H.; Yan, Q.; Wang, B.; Wang, Z.; Zhu, D.; Chen, H. Heterocyclic Compound of 4-Aminoquinazoline Useful in Treatment of Cancer and Its Application. CN Patent CN102942561A, 27 February 2013. 
28. Zhang, K.; Cao, D.; Xue, N.; Shi, Q.; Du, Y.; Dong, M. Phenylurea-Quinazoline Coupling Compounds: Preparation Method, Medicine Composition and Medicinal Use. CN Patent CN103382182A, 6 November 2013.

29. Zhang, X.; Peng, T.; Ji, X.; Li, J.; Tong, L.; Li, Z.; Yang, W.; Xu, Y.; Li, M.; Ding, J.; et al. Design, synthesis and biological evaluation of novel 4-anilinoquinazolines with C-6 urea-linked side chains as inhibitors of the epidermal growth factor receptor. Bioorg. Med. Chem. 2013, 21, 7988-7998. [CrossRef] [PubMed]

30. Buha, V.M.; Rana, D.N.; Chhabria, M.T.; Chikhalia, K.H.; Mahajan, B.M.; Brahmkshatriya, P.S.; Shah, N.K. Synthesis, biological evaluation and QSAR study of a series of substituted quinazolines as antimicrobial agents. Med. Chem. Res. 2013, 22, 4096-4109. [CrossRef]

31. Wang, H.; Liu, H.; Li, X.; Zhang, X.; Liu, Y.; Gong, N.; Zhou, Y.; Chen, K. Artemisinin Derivatives: Preparation Process and Application. PCT Patent WO2014023081A1, 13 February 2014.

32. Tang, T.; Yu, L.; Feng, H.; Yan, Q.; Wang, B.; Wang, Z.; Zhu, D.; Chen, H. 4-Quinazolinamine Heterocyclic Compound and Use Thereof. PCT Patent WO2014071824A1, 15 May 2014.

33. Yuan, J.; Han, N.; Yi, H.; Wang, Y.; Yang, S.; Wong, J.C. Potent Small Molecule Inhibitors of Autophagy, and Methods of Use Thereof. PCT Patent WO2014145512A3, 31 December 2014.

34. Lai, Y.; Pang, J.; Luo, M.; Chen, F.; Wang, P.; Zhang, Y. Preparation of $\alpha$-Cyano- $\alpha, \beta$-Unsaturated Amides as Antitumor Agents. CN Patent CN104774184A, 15 July 2015.

35. Zhang, K.; Cao, D.; Xue, N.; Shi, X.; Lu, K.; Gu, J.; Wang, L. Aryl Formyl Urea-Coupled Quinazoline Compound Useful in Treatment of Cancer and Its Preparation. CN Patent CN105753793A, 13 July 2016.

36. Min, J.; Guo, K.; Suryadevara, P.K.; Zhu, F.; Holbrook, G.; Chen, Y.; Feau, C.; Young, B.M.; Lemoff, A.; Connelly, M.C.; et al. Optimization of a novel series of ataxia-telangiectasia mutated kinase inhibitors as potential radiosensitizing agents. J. Med. Chem. 2016, 59, 559-577. [CrossRef] [PubMed]

37. Jiang, S.; Tu, Z.; Hao, H.; Yao, Y.; Qiu, Y.; Yao, H.; Qiang, L.; Chen, D. A Kind of Benzo-Aza Virtue Cyclics and Its Preparation Method and Application. CN Patent CN107674059A, 9 February 2018.

38. Bridges, A.J.; Zhou, H.; Cody, D.R.; Rewcastle, G.W.; McMichael, A.; Showalter, H.D.H.; Fry, D.W.; Kraker, A.J.; Denny, W.A. Tyrosine kinase inhibitors. 8. An unusually steep structure-activity relationship for analogues of 4-(3-bromoanilino)-6,7-dimethoxyquinazoline (PD 153035), a potent inhibitor of the epidermal growth factor receptor. J. Med. Chem. 1996, 39, 267-276. [CrossRef] [PubMed]

39. Sun, Y.T.; Wang, G.F.; Yang, Y.Q.; Jin, F.; Wang, Y.; Xie, X.Y.; Mach, R.H.; Huang, Y.S. Synthesis and pharmacological evaluation of 6,7-dimethoxy-1,2,3,4-tetrahydroisoquinoline derivatives as sigma-2 receptor ligands. Eur. J. Med. Chem. 2018, 147, 227-237. [CrossRef] [PubMed]

40. Ulrich, H. The Chemistry of Imidoyl Halides; Plenum Press: New York, NY, USA, 1968; pp. 55-56.

41. Li, H.G.; Kim, C.K.; Lee, B.S.; Kim, C.K.; Rhee, S.K.; Lee, I. Nucleophilic substitution at the imidoyl carbon atom: Intermediate mechanistic and reactivity behavior between carbonyl and vinyl carbon substitution. J. Am. Chem. Soc. 2001, 123, 2326-2333. [CrossRef] [PubMed]

42. Manley, P.J.; Bilodeau, M.T. A mild method for the formation and in situ reaction of imidoyl chlorides: Conversion of pyridine-1-oxides to 2-aminopyridine amides. Org. Lett. 2002, 4, 3127-3129. [CrossRef] [PubMed]

43. Wang, L.; Yu, X.; Wang, W.; Xiao, Y. Preparation Method for Afatinib Intermediate 6-Nitro-7-Chloro-4-Quinazolinone. CN Patent CN105712940A, 29 June 2016.

44. Abraham, R.J.; Byrne, J.J.; Griffiths, L.; Perez, M. ${ }^{1} \mathrm{H}$ chemical shifts in NMR: Part 23, the effect of dimethyl sulphoxide versus chloroform solvent on ${ }^{1} \mathrm{H}$ chemical shifts. Magn. Reson. Chem. 2006, 44, 491-509. [CrossRef] [PubMed]

(C) 2020 by the authors. Licensee MDPI, Basel, Switzerland. This article is an open access article distributed under the terms and conditions of the Creative Commons Attribution (CC BY) license (http://creativecommons.org/licenses/by/4.0/). 